\title{
Dealing with Dictators ${ }^{1}$
}

\author{
Forthcoming in Journal of Political Philosophy \\ Chris Armstrong, University of Southampton
}

\section{$\underline{\text { Introduction }}$}

Dictatorship is a great stain upon our world. Dictators treat their subjects purely as means to their own aggrandizement, and not as agents with a right to participate in self-government. Moreover dictators frequently, though not always, commit great harms: starting wars, brutalizing dissidents, persecuting minorities, and squandering resources which could otherwise be used to advance the common good.

The question of how outsiders - including outsiders living in societies committed in word, if not always in deed, to the core principles of liberal democracy - ought to engage with or respond to dictatorial regimes, though, is a thorny one. Difficult questions arise in the context of overseas aid, for instance, as states and NGOs grapple with how to act in a situation where their support might bolster repressive regimes. ${ }^{2}$ But the focus here will be upon international trade. In recent years, a number of scholars have argued that for liberal democracies to allow their citizens and corporations to trade with dictatorships can also serve to entrench dictators' positions, and even make the emergence of dictatorships more likely. To avoid such outcomes,

\footnotetext{
${ }^{1}$ For helpful advice, I would like to thank two anonymous referees, James Christensen, Cecile Fabre, Jonathan Havercroft, Eszter Kollar, Cara Nine, Kieran Oberman, David Owen, James Pattison, and Patrick Tomlin, as well as audiences as the Katholieke University Leuven, University College Cork, and the University of Oslo.

${ }^{2}$ Jennifer Rubenstein (2015) Between Samaritans and States: The Political Ethics of Humanitarian INGOs. Oxford: Oxford University Press, 87-114.
} 
our governments ought to forbid citizens and corporations from buying goods from societies blighted by dictatorship. Leif Wenar has recently argued that we should stop buying natural resources from countries where governments are not accountable to citizens in even a minimal sense. ${ }^{3}$ Thomas Pogge has argued that our willingness to trade no-questions-asked with dictatorships serves to protect - and even incentivise the emergence of - brutal regimes, and as such violates a negative duty not to harm the global poor. In at least some circumstances, we are morally obliged to break off trade - including cases where initially legitimate governments in vendor countries slide away from democracy. ${ }^{4}$ Shmuel Nili has claimed that democracies should not trade with dictatorships at all, since doing so would be a hypocritical violation of our liberal and democratic commitments. ${ }^{5}$

These arguments all suggest that morality requires the cessation of, or at the very least serious restrictions on, trade with dictatorships, but they specify these restrictions in different ways. The kinds of trade which ought to be prohibited can be calibrated more broadly, or more narrowly, on at least two scalar dimensions. We might be obliged, more narrowly, to cease all purchases from dictators or their cliques only, or, more broadly, to cease all purchases from societies blighted by their rule whether they are routed through the ruling elite or not. Or we might argue for some intermediate position. And we might be obliged to cease purchases of some kinds of goods, more narrowly, all goods, more broadly, or something in between. Nili's account appears to be broadly specified on both dimensions. Pogge's and Wenar's focus appears to be on purchases from unrepresentative ruling elites. And their focus is relatively

\footnotetext{
${ }^{3}$ Leif Wenar (2016) Blood Oil. Oxford: Oxford University Press, 263-336.

${ }^{4}$ Thomas Pogge (2002) World Poverty and Human Rights. Cambridge: Polity, 152-73. Pogge's proposal is conditional. Democratic states ought to pass laws stating that outsiders can no longer buy public property from them if they slide back to authoritarianism. If they pass such laws, and later slide into authoritarianism, outsiders should consider popular consent to such sales to be withdrawn. We will return to the issue of consent later.

${ }^{5}$ Shmuel Nili (2011) "Conceptualizing the Curse: Two Views On Our Responsibility for the Resource Curse," Ethics \& Global Politics 4.2: 103-124.
} 
narrow in our second sense too: they concentrate on the sale of public property, rather than all goods and services. ${ }^{6}$

In what follows I am interested in the full range of arguments here. I will consider both arguments for widely-applied restrictions on purchases of the kind endorsed by Nili, and arguments for narrower restrictions on trade of the sort associated with Pogge and Wenar. In principle it might be that restrictions which are narrower on one or both dimensions are easier to defend - but that remains to be seen. It is also worth clarifying that the claim I am interested in is not that we should cease trade with dictatorships when they engage in genocide, mass atrocities, and ethnic cleansing. The claim I am interested in holds that we should cease trade (in the specified ways) with dictatorships whether they engage in these activities or not. Likewise, I will not be investigating the claim that we should cut off trade whenever trading renders us beneficiaries from injustice, or complicit in exploitation. Neither concern, after all, gives us reasons for breaking off trade with dictatorships in particular. The arguments I am investigating, by contrast, attempt to supply particular reasons for doing just that.

My focus will be on purchases, since arguments that there are some goods - such as weapons - which we should not sell to dictatorships have already received considerable attention. ${ }^{7}$ I believe that arguments for restrictions on our purchases possess some initial plausibility. If dictatorship is a great moral bad, then we might think that we should make strenuous efforts not to be complicit in it - and given the projects our money might serve, providing dictators with a steady stream of revenue looks like an important example of such complicity. ${ }^{8}$ Some sectors of international trade might be especially pernicious in their effects.

\footnotetext{
${ }^{6}$ Wenar's focus in Blood Oil is still more narrow, as the book's title suggests. Oil might indeed be an especially pressing case, given the pathologies associated with dependence on it. But if the claim is that what is owned by the people should not be bought from dictators, the argument should extend, like Pogge's, to all forms of public property.

${ }^{7}$ See e.g. James Christensen (2019) "Arming the Outlaws: On the Moral Limits of the Arms Trade," Political Studies 67.1: 116-31.

${ }^{8}$ For an analysis of various forms of complicity see Chiara Lepora and Robert Goodin (2013) On Complicity and Compromise. Oxford: Oxford University Press, 17-30.
} 
The resource trade, for instance, delivers a source of income which might insulate leaders from citizens' demands for political inclusion. The ready availability of resource income is sometimes said to reduce rulers' need to tax, and hence to engage with the demands of, ordinary citizens. ${ }^{9}$ There are several possible arguments for the conclusion that we are duty-bound to stop buying from dictatorships, however. To make progress, it is helpful to distinguish between 'instrumental' and 'non-instrumental' arguments. Instrumental arguments suggest that we ought to cease trade in order to advance valuable goals such as human rights or democracy (in societies blighted by dictatorship). Non-instrumental arguments do not focus on outcomes. Instead they suggest that the cessation of purchases is morally imperative insofar as it expresses an appropriate repugnance for dictatorship and oppression, for instance, or signals due respect for values such as property rights or consent. These arguments suggest that cessation may be required even if it does not improve the situation of those ruled over by dictators - and even, perhaps, if cessation makes things worse for them.

I will examine each type of argument in what follows. My overall conclusion will be that we ought to be very cautious, in fact, about withdrawing from trade with dictatorships. When it comes to instrumental arguments, an engagement with the extensive empirical and normative discussions that have taken place on the topic of economic sanctions in recent years reveals that we have serious grounds for concern that the cessation of trade with dictatorships will not achieve its stated ends, and may make things worse - and perhaps much worse - for the people we are trying to help. I will also suggest that while cessation may be more successful in advancing its non-instrumental goals, the cases in which we are obliged all things considered to cease purchases are rarer than we might suppose. Finally, I will inject a useful comparative element into the discussion by addressing empirical work on what typically happens when we extend and deepen, rather than withdrawing, trade with dictatorships. If the relevant empirical

\footnotetext{
${ }^{9}$ See e.g. Michael Ross (2012) The Oil Curse. Princeton: Princeton University Press, 27-62.
} 
findings are robust, they throw interesting new light on our question. In the end, I will argue, at least in the majority of cases we are likely to confront, the withdrawal of trade with dictatorships will not be morally required - and indeed may be impermissible. Surprisingly, perhaps, our best response to the horror of dictatorship may turn out to be to trade more, rather than less.

\section{$\underline{\text { Instrumental Arguments }}$}

Terminating our trading relationship with dictatorships is a paradigmatic example of the economic sanction. Though refusing to sell goods to dictatorships is probably the more common strategy, refusing to buy from them is also a familiar element of many packages of sanctions. The sanctions imposed on Iraq following the Gulf War, for example, centrally involved constraints on its ability to sell oil - though these constraints were eventually moderated under the 'oil for food' scheme. Similar embargoes have been placed on Iran and Syria in more recent years. ${ }^{10}$ Blocking purchases of goods such as oil, diamonds or gold removes from dictators a major source of income - income which could otherwise fund weapons transfers and the repressive apparatus of the state (among other things).

It is important to note that the cessation of trade our critics have in mind is distinct from the individual consumer boycott. We might suppose that individual consumers exercise an important freedom in refusing to buy from certain producers, or certain places - and that the justificatory bar for such boycotts ought therefore to be set rather low. ${ }^{11}$ But the proposals under review remove from individual consumers this freedom to choose. On Wenar's proposal, for

\footnotetext{
${ }^{10}$ Erica Moret (2015) "Humanitarian Impacts of Economic Sanctions on Iran and Syria," European Security 24.1: 120-140.

${ }^{11}$ For an analysis of moral limits to the individual freedom to boycott, see Waheed Hussain (2012) "Is Ethical Consumerism an Impermissible Form of Vigilantism?" Philosophy \& Public Affairs 40.2: 111143.
} 
instance, our government should act to forbid individual consumers and corporations from buying resources from the target country. And it should stand ready to employ coercive legal measures in order to enforce cessation. ${ }^{12}$ As Cecile Fabre observes, economic sanctions interfere in economic relationships between consenting parties. ${ }^{13}$ Indeed - since unilateral sanctions imposed by a single country are rarely effective - states will often go further, employing what Fabre calls 'secondary sanctions' in order to discourage actors in other states from trading with the target - again with the threat of coercive measures in the background. This kind of restriction requires a more powerful justification. ${ }^{14}$ The justificatory bar may be lifted higher still if, as I suggest in the final section of this paper, trade typically engenders at least some positive outcomes which sanctions would thwart.

In practice, sanctions have often been instruments of power politics, aimed at pressuring other states to fall in line with various foreign policy goals. But they also have objectives which are normatively plausible on their face. In this section, I will focus on instrumental arguments for the withdrawal of trade. Sometimes, to be sure, sanctions seek to stop mass atrocities, genocide or the invasion of other states. I will not challenge the idea that sanctions - or indeed the use of force - would be appropriate in such circumstances. The claim I am examining is that we ought to cease trade with dictatorships even when they do not engage in these great crimes. The instrumental argument I am interested in is aimed at preventing or deterring more quotidian offences. For instance, the cessation of purchases might seek to prevent the breaches of physical integrity rights which often occur in dictatorships, including police brutality, arbitrary detention, and torture. Or it might seek to promote rights of political participation, setting dictators on the path to democratic reform, or at least engendering more narrow forms

\footnotetext{
${ }^{12}$ Wenar, Blood Oil, 283-8.

${ }^{13}$ Cecile Fabre (2018) Economic Statecraft. Oxford: Oxford University Press, at 29.

${ }^{14}$ Daniel Weinstock argues, relatedly, that whereas boycotts usually face a low justificatory burden, imposing them coercively imposes a greater burden. Weinstock (2018) "Dissidents and Innocents: Hard Cases for a Political Philosophy of Boycotts," Journal of Applied Philosophy (earlyview).
} 
of accountability. Economic sanctions also sometimes aim at regime change - though insofar as regime change is desirable, its value will primarily lie, we might suppose, in the ensuing gains to human rights or democracy.

Fortunately, prima facie-plausible criteria with which to assess the instrumental effects of sanctions are not hard to come by. In recent years, there has been a small explosion of literature on the morality of economic sanctions. For the most part, this new literature seeks to apply concepts which are more familiar from just war theory. Just war theorists have attempted to isolate conditions which must be in place for the instigation of lethal force to be justified. The key thought for our purposes has been that at least some such conditions are relevant in the case of sanctions too. To be sure, we might well believe that the justificatory standard for economic sanctions should be lower than in the case of military force. When we stop buying goods from dictatorships, we are not launching lethal 'kinetic' actions, as just war theorists sometimes put it. We are simply withdrawing from trade - albeit with the potential use of coercion against citizens, or third parties, who refuse to go along with cessation lurking in the background. As Fabre puts it, 'although we might end up killing people, we do so by interfering with contractual economic and financial relationships. A precise philosophical justification for sanctions must be sensitive to that distinction. ${ }^{15}$

But just war conditions including effectiveness and proportionality appear to be relevant nevertheless. The standard of effectiveness concerns the probability that the goals of our actions will be brought about by those actions; the standard of proportionality, by contrast, requires a comparison of the morally weighted harms our actions will produce with the morally weighted harms which would come to pass if we did not act. ${ }^{16}$ If the justification for the cessation of trade is going to be instrumental in the sense that it aims to improve the situation

\footnotetext{
${ }^{15}$ Fabre, Economic Statecraft, 34.

${ }^{16}$ See Henry Shue (2018) "Last Resort and Proportionality," in Seth Lazar and Helen Frowe (eds) The Oxford Handbook of the Ethics of War (Oxford: Oxford University Press), 260-76.
} 
of individual subjects in dictatorships, then it would be very odd not to apply these standards to our actions. The negative consequences our choices generate at least ought to be no greater than the harms that would come about if we stood by and did nothing; and we must be reasonably confident that our actions are going to achieve their stated ends.

On this basis, however, there are grounds for serious caution. Sanctions became very popular in the years immediately following the Cold War. The United Nations Security Council imposed economic sanctions twice between 1945 and 1990, but 11 times during the 1990s. The US imposed sanctions on 35 countries between 1993 and 1996 alone. ${ }^{17}$ But a backlash did not take long to occur. By the end of the 90s it had been claimed, for instance, that sanctions had contributed to more deaths in the decade since the Cold War than all weapons of mass destruction throughout history. ${ }^{18}$ At the same time, it was alleged that resort to sanctions made political or human rights reform less, rather than more, likely. ${ }^{19}$ By the early years of the twenty-first century, the view that sanctions are successful only in relatively rare circumstances was being described as the 'traditional' and 'dominant' view. ${ }^{20}$ Those claims are sobering. Let's consider worries about the effectiveness of sanctions first, before turning to the question of their proportionality.

\footnotetext{
${ }^{17}$ Joy Gordon (1999) “A Peaceful, Silent, Deadly Remedy: The Ethics of Economic Sanctions," Ethics \& International Affairs 13: 123-142.

${ }^{18}$ John Mueller and Karl Mueller (1999) "Sanctions of Mass Destruction," Foreign Affairs 78.3: 43-53, at 43.

${ }_{19}$ Peksen, Dursun and A. Cooper Drury (2010) "Coercive or Corrosive: The Negative Impact of Economic Sanctions on Democracy," International Interactions 36.3: 240-264; Oechslin, Manuel (2014) "Targeting Autocrats: Economic Sanctions and Regime Change," European Journal of Political Economy 36.1: 24-40.

${ }^{20}$ Jon Hovi, Robert Huseby, and Detlef Sprinz (2005) "When Do (Imposed) Economic Sanctions Work?" World Politics 57.4: 479-499.
} 
Effectiveness. International relations scholars may not agree about very much, but there does appear to be consensus that sanctions fail far more often than they succeed. ${ }^{21}$ The live disagreement concerns the precise ratio of failure to success. On what is widely held to be the most optimistic calculation, sanctions fail at least twice as often as they succeed. ${ }^{22}$ An influential reanalysis of the same cases suggested that the success rate was less than 5\%, however. ${ }^{23}$ The authors later revised down their estimate, declaring that sanctions were partly successful in effecting major policy change no more than $30 \%$ of the time. ${ }^{24}$ In some of these successful cases, note, the target countries were democracies. Indeed sanctions are sometimes said to be more effective against democracies than against dictatorships. ${ }^{25}$ One explanation is that it is easier for outsiders to engender policy change in democracies, first because leadership turnover is more routine (there are procedures for the regular rotation of leaders), and second because the costs to defeated leaders are less severe. In dictatorships, by contrast, there are few opportunities for leadership turnover, and turnover can have very serious consequences for defeated leaders. Both facts make reform less likely in autocracies, other things being equal.

Moreover, it is widely believed that sanctions are often counter-productive. The empirical literature sketches two key mechanisms here. First there is what we can call a 'resource concentration' effect. When dictators are starved of a stream of resources, they

\footnotetext{
${ }^{21}$ Allen, Susan (2005) "The Determinants of Economic Sanctions Success and Failure," International Interactions 31.2: 117-138; Lektzian, David and Mark Souva (2007) "An Institutional Theory of Sanctions Onset and Success," Journal of Conflict Resolution 51.6: 848-871.

${ }^{22}$ Gary Hufbauer, Jeffrey Schott and Kimberly Elliott (1985) Economic Sanctions Reconsidered, first edition. Washington D.C.: Institute for International Economics, 93.

${ }^{23}$ Robert Pape (1997) "Why Economic Sanctions Do Not Work," International Security 22.2: 90-136.

${ }^{24}$ Gary Hufbauer, Jeffrey Schott, Kimberly Elliott and Barbara Oegg (2007) Economic Sanctions Reconsidered, third edition. Washington D.C.: Peterson Institute for International Economics, 159. Note that these figures evaluate success in achieving a variety of ends, not all of which reduce to improving democracy or human rights. There appears to be little literature assessing the effectiveness of sanctions aimed at promoting democracy and human rights in particular, though Peksen suggests that those aiming at promoting human rights are especially likely to be ineffective. Dursun Peksen (2009) "Better or Worse? The Effect of Economic Sanctions on Human Rights," Journal of Peace Research 46.1: 59-77.

${ }^{25}$ Nikolay Marinov (2005) “Do Economic Sanctions Destabilize Country Leaders?” American Journal of Political Science 49.3: 564-576.
} 
concentrate what they do have even more exclusively on their immediate allies, in order to secure their continued support. ${ }^{26}$ Second, there is what we can call a 'threat / repression' effect. Sanctions often encourage dissidents to mobilise; in many cases that is their point. But dictators respond to such threats to their position by cracking down even more harshly on real or perceived opposition. ${ }^{27}$ Along either modality, sanctions can cause serious harms to the people we are trying to help. ${ }^{28}$ As a result, they have been shown to be associated with significantly higher violations of physical integrity rights in the target country compared to the status quo. ${ }^{29}$ Sanctions also frequently generate backlash effects, with leaders invoking nationalist rhetoric to blame outsiders for the ensuing deprivation. ${ }^{30}$ They appear to be associated with a deterioration in the rule of law and an increase in corruption too, as citizens are driven to find new sources of goods and / or income, with members of the elite often profiting from the new opportunities this opens up. ${ }^{31}$

Given the apparent consensus that sanctions only work in a minority of cases, it is not surprising that considerable effort has been put into identifying what the most propitious circumstances are in which to deploy them. Kaempfer, Lowenberg and Mertens have suggested that sanctions are more likely to work 'if there exists within the target country a reasonably well-organized opposition group whose political effectiveness potentially could be enhanced as a consequence of sanctions. In the absence of such a group, the sanctions might only strengthen the regime's pursuit of its objectionable policy by helping to rally public opinion

\footnotetext{
${ }^{26}$ Gordon, "A Peaceful, Silent, Deadly Remedy," 125.

${ }^{27}$ Reed Wood (2008) "“A Hand Upon the Throat of the Nation': Economic Sanctions and State Repression, 1976-2001," International Studies Quarterly 52.3: 489-513.

${ }^{28}$ Mueller and Mueller, "Sanctions of Mass Destruction."

${ }^{29}$ Wood, "A Hand Upon the Throat," at 503; Peksen, "Better or Worse."

${ }^{30}$ Johan Galtung (1967) "On the Effects of International Economic Sanctions, With Examples from the Case of Rhodesia," World Politics 19.3: 378-416; Gordon, "A Peaceful, Silent, Deadly Remedy," 1345 .

${ }^{31}$ Daniel Drezner (2011) "Sanctions Sometimes Smart: Targeted Sanctions in Theory and Practice," International Studies Review 13.1: 96-108; Wood, "A Hand Upon the Throat"; Lori Damrosch (1994) "The Collective Enforcement of International Norms Through Economic Sanctions," Ethics \& International Affairs 8: 59-75.
} 
around the government. ${ }^{32}$ Escriba-Folch and Wright, meanwhile, suggest that sanctions make 'personalist' dictators somewhat more vulnerable to domestic opposition, but have no positive effect (and perhaps a negative effect) in the case of single-party and military dictatorships. ${ }^{33}$ Finally, it has been suggested that long-running dictatorships are the least plausible targets, at least when it comes to political reform: 'Enduring autocracies are least likely to justify the imposition of broad and severe sanctions to promote democratic change,' claim Marinov and Nili. In such cases, 'it is not clear how even a high cost imposed on the population at large can translate into political action against the regime. The collective action problems inherent in organizing against a despotic regime, when there are no recurring elections to serve as focal points, are too formidable. ${ }^{34}$ In summary, the odds of success for economic sanctions do not appear to be good, and negative outcomes are common. But effective sanctions packages may include those targeting regimes which are relatively new, and / or personalist in character, and / or which already face major organised opposition.

Proportionality. Even if sanctions can sometimes achieve valuable goals, can they do so without generating excessive moral costs? The challenge from proportionality appears morally more grave than that of effectiveness. For a policy to fail to do good is one thing. But for it to do more harm than good is more serious still. The emphasis on proportionality directs our attention to comparative judgements about the effects of sanctions versus doing nothing on the one hand, and versus other accessible courses of action on the other. ${ }^{35}$ One implication of the

\footnotetext{
${ }^{32}$ William Kaempfer, Anton D. Lowenberg, and William Mertens (2004) "International Economic Sanctions Against a Dictator," Economics \& Politics 16.1: 29-51, at 31.

${ }^{33}$ Abel Escribà-Folch and Joseph Wright (2010) "Dealing With Tyranny: International Sanctions and the Survival of Authoritarian Rulers," International Studies Quarterly 54.2: 335-359.

${ }^{34}$ Nikolay Marinov and Shmuel Nili (2015) "Sanctions and Democracy," International Interactions 41.4: 765-778, at 774 .

${ }^{35}$ James Pattison (2018) The Alternatives to War. Oxford: Oxford University Press, 6. In what follows I will concentrate on the effects on the subjects of dictatorships. But if - as seems likely - sanctions have costs for citizens of purchasing countries, those would have to be taken into account in any proportionality calculation. So too would costs for third parties, which some sanctions scholars have
} 
comparative nature of judgements about proportionality is that the fact that sanctions often harm the innocent cannot by itself be considered a decisive objection against their use. ${ }^{36}$ After all, doing nothing also means that subjects will continue to experience abuses of their human rights.

How, then, do sanctions fare in terms of proportionality? Generalised trade sanctions are widely agreed to be a very blunt instrument of foreign policy. Their effects on domestic populations are widespread and diffuse. If anything, they tend not to hurt the target regime, but to hurt its opponents instead. ${ }^{37}$ The resource concentration and threat / repression effects provide the causal mechanisms here: dictators typically respond to sanctions by diverting still more resources to their power base, and stepping up repression against dissidents. Sanctions are often associated with a deteriorating human rights situation, ${ }^{38}$ not least because they depress the economy, worsen public health and education provision, and subject civil society to increased repression. ${ }^{39}$ On one well-known analysis, extensive sanctions make 'disappearances' of dissidents $115 \%$ more likely, incidents of torture $61 \%$ more likely, and extra-judicial killings $64 \%$ more likely, with multilateral sanctions associated with a greater negative effect in each case compared to unilateral sanctions. Worryingly, these accentuating effects are more pronounced in the case of sanctions aimed at preventing human rights abuses, when compared to sanctions aiming at other goals. ${ }^{40}$ Sanctions have also tended to disproportionately impact upon women. ${ }^{41}$ According to Lori Damrosch, 'The overwhelming

suggested can be significant. See e.g. Michael Canes (2000) "Country Impacts of Multilateral Oil Sanctions," Contemporary Economic Policy 18.2: 135-44.

${ }^{36}$ Fabre, Economic Statecraft, 49.

${ }^{37}$ Gordon, "A Peaceful, Silent, Deadly Remedy": Drezner, "Sanctions Sometimes Smart."

${ }^{38}$ Yitan Li and A. Cooper Drury (2004) "Threatening Sanctions When Engagement Would Be More Effective: Attaining Better Human Rights in China," International Studies Perspectives 5.4: 378-394.

${ }^{39}$ Thomas Weiss et al, "Economic Sanctions and their Humanitarian Impacts: An Overview," in Weiss et al (eds 1997) Political Gain and Civilian Pain: Humanitarian Impacts of Economic Sanctions. Lanham: Rowman and Littlefield, 1-34.

${ }^{40}$ Peksen, "Better or Worse?" 69-74.

${ }^{41}$ Scott Wisor (2016) "Conditional Coercion versus Rights Diagnostics: Two Approaches to Human Rights Protection," Politics, Philosophy \& Economics 15.4: 405-23, at 408; A. Cooper Drury and 
impression remains that internationally sponsored sanctions have had the perverse effects of enriching the targeted elites while simultaneously causing ever greater impoverishment of civilian populations. ${ }^{42}$ Those we are trying to empower - members of the domestic opposition - appear more likely to suffer than the average citizen.

None of this rules out the use of economic sanctions. If the alternative is to allow mass atrocities or genocides to occur, then it has been argued that sanctions might be preferable even if they are associated with an increase in serious human rights abuses - because sanctions might, for instance, spread harms more thinly and evenly compared to mass killings. ${ }^{43}$ But note, first, that even if the comparative case can be made in instances where dictators are engaged in mass atrocities and foreign aggression, it remains to be made in the case of what Michael Walzer once called the 'ordinary oppression' typical of dictatorships ${ }^{44}$ : the widespread deprivation of political rights, the imprisonment of dissidents, and so on. These quotidian offences are our topic in this paper, and here the comparative argument looks on its face to be harder to make. Recall, second, that sanctions must be compared not only to doing nothing, but also to other options, some of which might perform better on the score of proportionality. As such a justification of sanctions must also involve an analysis of any other plausible and effective responses to dictatorship - on which more later.

\section{Improving the Performance of Sanctions?}

The preceding section considered the prospects for cessation if what we care about are the consequences for the oppressed subjects of dictatorships. We have seen that the likely

\footnotetext{
Dursun Peksen (2014) "Women and Economic Statecraft: The Negative Impact International Economic Sanctions Visit on Women," European Journal of International Relations 20.2: 463-90.

${ }^{42}$ Damrosch, "The Collective Enforcement of International Norms," 74.

${ }^{43}$ Pattison, Alternatives to War, 66-7.

${ }^{44}$ Michael Walzer (1980) "The Moral Standing of States: A Response to Four Critics," Philosophy and Public Affairs 9.3: 209-229, at 218.
} 
effectiveness of the withdrawal of trade is highly uncertain, and that there are, meanwhile, serious concerns about proportionality. There is room, of course, for disagreement about the precise degree of responsibility we - as outsiders - bear for the negative outcomes which are often associated with economic sanctions. Fabre suggests that even if we are merely intervening agents in the negative humanitarian effects associated with sanctions, with the costs being directly imposed by dictators themselves, then we are 'still responsible in some sense for those costs, and must take them into account when deciding whether sanctions are justified overall. ${ }^{45}$ I believe Fabre is right here, but the crucial point for my purposes is the final clause of that sentence. If we are judging sanctions on the basis of their instrumental effects, then whoever is responsible for these harms, their scale needs to be taken into account in a reckoning of the effectiveness and proportionality of sanctions.

Here, as we have seen, we have serious grounds for concern. It has been suggested that these grounds are sufficient, in fact, to place pressure on the widespread idea that we ought to see the deployment of military force as the last resort in cases of severe repression. In some cases, military force might even be preferable to sanctions, if its effects are more concentrated, shorter in duration, and / or more closely targeted at repressive elites rather than ordinary citizens. ${ }^{46}$ Whether that judgment is sound or not, these worries certainly justify a serious investigation of alternative measures which might be associated with less damaging effects on civilian populations.

\section{i. Smarter Sanctions}

Perhaps we can improve sanctions' performance, however, by being more selective or 'smart' in their imposition. In his book Blood Oil, Leif Wenar argues that outsiders should break off

\footnotetext{
${ }^{45}$ Fabre, Economic Statecraft, 54.

${ }^{46}$ David Fisher (2011) Morality and War: Can War Be Just in the Twenty-first Century? Oxford: Oxford University Press, 73.
} 
purchases of oil (only) from societies where rulers are not even minimally accountable to citizens in their decision-making about the resource trade. A Clean Hands Act would make it illegal in domestic law for individuals or corporations to continue to purchase oil from blacklisted countries. Should actors in other countries continue to do so, tariffs could be placed on imports from those countries, with the proceeds being held in a Clean Hands Trust until such time as the target country achieved a minimal degree of accountability in the resource trade. ${ }^{47}$ The proposal is therefore selective in two senses. First, the cessation of trade is restricted to the 'worst of the worst' when it comes to accountability, targeting those regimes which most clearly fail on publicly-available indexes of human rights or political inclusion. ${ }^{48}$ Second, it focuses on specific goods which are closely associated with poor governance. The primary focus is on oil, though in principle the proposal might be applied to other natural resources associated with conflict or authoritarianism too. ${ }^{49}$

It seems plausible on its face that in specifying the target of sanctions more closely in these two senses, their performance on the criteria of effectiveness and proportionality might be improved. In fact, however, serious worries remain in relation to both standards. When it comes to effectiveness, we have already noted evidence that targeting the worst rulers is unlikely to improve the ratio of success to failure. In fact the opposite appears to be the case. ${ }^{50}$

\footnotetext{
${ }^{47}$ Blood Oil, 289-91. Wenar in fact denies that his proposal amounts to an economic sanction: sanctions, he claims, are punitive, whereas his proposal aims to realign incentives in the direction of greater accountability. Leif Wenar (2018) "Reply to Blake and Mehdiyeva," in Wenar et al, Beyond Blood Oil. Lanham MA: Rowman and Littlefield, 119-31, at 124. In fact, sanctions have many goals aside from punishment, and they very often aim precisely to discourage some form of behaviour (such as the abuse of human rights, or external aggression), and to incentivise adherence to some norm or goal by holding out the promise that restrictions on trade will be lifted once compliance is achieved. See Hufbauer et al (2007) Economic Sanctions Reconsidered, 3-7; Fabre, Economic Statecraft, chapter 2; Pattison, Alternatives to War, 40-2. As such evidence on the performance of sanctions appears relevant when assessing these proposals.

${ }^{48}$ Wenar, "Beyond Blood Oil," in Wenar et al, Beyond Blood Oil. Lanham MA: Rowman and Littlefield, 1-35, at 19.

${ }^{49}$ Ibid, 20.

${ }^{50}$ David Letzkian and Mark Souva (2007) "An Institutional Theory of Sanctions Onset and Success," Journal of Conflict Resolution 51.6: 848-71; Marinov, "Do Economic Sanctions Destabilize Country Leaders?"; Marinov and Nili, "Sanctions and Democracy."
} 
One explanation is that democratic rulers fear being punished electorally if sanctions bite, whereas dictators need not. A second explanation is that sanctions do little to alter the domestic or regional balance of power which dictators inhabit. ${ }^{51}$ As a result, authoritarian leaders are said to have little incentive to concede to economic coercion in most situations we are likely to confront. ${ }^{52}$ It might well be easier to build international political support for the cessation of trade with the worst regimes, but the evidence suggests that focusing on those regimes is likely to mean a deterioration rather than an improvement in rates of success.

It might be thought, however, that focusing sanctions on one good, such as oil, will pay dividends. If oil sales fund military expenditure, for instance, we might suppose that sanctions will serve to reduce that expenditure and hence leave dictators more vulnerable to reform pressure. In fact, the opposite appears to be the case. Sanctioned dictators increase military spending - probably in response to perceived threats - and they do so by reducing spending on public goods for ordinary citizens: 'when survival is at stake, developmental concerns are left aside. ${ }^{53}$ Sanctions on oil-producing countries appear to be even less likely than average to destabilize rulers. ${ }^{54}$ Van de Graaf has suggested that oil sanctions are most plausible in specific economic conditions where buyers exert greater-than-usual power, and where the oil price already happens to be unusually low. In other cases, he suggests, sanctioned countries can usually ride out oil sanctions without too much difficulty. ${ }^{55}$

\footnotetext{
${ }^{51}$ Wisor, "Conditional Coercion versus Rights Diagnostics," 408.

${ }^{52}$ Susan Allen (2005) "The Determinants of Economic Sanctions' Success and Failure," International Interactions 31.2: 117-138, at 133.

${ }^{53}$ Abel Escribà-Folch (2012) "Authoritarian Responses to Foreign Pressure: Spending, Repression, and Sanctions," Comparative Political Studies 45.6: 683-713, at 699. Hultman and Peksen also report that, whereas arms embargoes may reduce violence within target countries, sanctions in general appear to correlate with increased violence. Lisa Hultman and Dursun Peksen (2017) "Successful or Counterproductive Coercion? The Effect of International Sanctions on Conflict Intensity," Journal of Conflict Resolution 61.6: 1315-39.

${ }^{54}$ Escribà-Folch and Wright, "Dealing With Tyranny," 355.

55 Thijs Van de Graaf (2013) "The 'Oil Weapon' Revisited: Sanctions Against Iran and US-EU Structural Power," Middle East Policy 20.3: 145-63, at 146.
} 
There does, however, appear to be at least once case in which oil sanctions have been successful in shifting state policy. Wenar notes that oil sanctions on Iran appear to have been pivotal in engendering a shift towards denuclearisation. ${ }^{56}$ But it is useful, I suggest, to look at the Iranian case in a slightly broader context. Sanctions on Iranian oil exports have now been in place for four decades. The US has not bought a single barrel of Iranian oil since 1991, and has placed considerable pressure on third parties to conform to that policy. ${ }^{57}$ It does appear that the precipitous drop in global oil prices in 2014, which seriously weakened Iran's economy, encouraged it to seek an easing of sanctions. ${ }^{58}$ Decades of sanctions have signally failed, however, in their principal and longstanding objectives: to deter Iran from sponsoring terrorism, and to push it down the road to political reform. ${ }^{59}$ At the time of writing, the Iran nuclear deal is under considerable pressure, and Iran has reportedly stepped back from key nuclear-related commitments. ${ }^{60}$ But whether it ultimately succeeds or fails, we are still waiting for examples of oil sanctions engendering political inclusion or human rights reform.

We must also address concerns about proportionality; but here too oil sanctions experience difficulties. When Fabre discusses the cessation of sales of goods to brutal regimes, she suggests that the case is going to be easier to make in the case of 'single-purpose goods' which are key to regime survival - such as weapons - and all but impossible to make in the case of 'dual purpose goods' which can be used to advance repressive and less objectionable

\footnotetext{
${ }^{56}$ Wenar, "Reply to Blake and Mehdiyeva," 124.

${ }^{57}$ Van de Graaf, "The 'Oil Weapon' Revisited," 147.

${ }^{58}$ There also appears to have been a greater willingness, especially in Europe, to strike a deal in part because of the ongoing humanitarian impact of sanctions. Critics within the European Union suggested that oil sanctions were having such broad and indiscriminate effects that, though technically 'targeted' or 'smart,' these sanctions in practice reproduced the effects of comprehensive sanctions - which the EU had repudiated as a legitimate foreign policy instrument. Moret, "Humanitarian Impacts of Economic Sanctions," 120.

${ }^{59}$ Jeffrey Schott (2012) "Economic Sanctions Against Iran: Is the Third Decade a Charm?" Business Economics 47.3: 190-192, at 191.

${ }^{60}$ This has led to suggestions that sanctions will resume once again. Jean-Baptiste Vey and Ahmed Rasheed, "France Suggests Sanctions Could be Reimposed if Iran Reneges on Deal," Reuters $7^{\text {th }}$ May 2019.
} 
goals. As a result of uncertainty about the humanitarian effects of generalised sanctions, 'sanctioning parties must opt for highly targeted sanctions - with respect to their objects and the individuals against whom they apply. ${ }^{61}$ But when we buy goods from dictators, we send in the other direction the dual purpose good par excellence: money. Cutting off a major source of foreign income therefore appears highly likely to impact negatively on the civilian population. The 'resource concentration effect' suggests that the cessation of purchases will diminish the provision of public goods. ${ }^{62}$ In practice, oil sanctions do appear to be associated with significant economic downturns and large-scale reductions of state spending on civilians.

This effect appears to have been borne out in every major recent case of oil sanctions. In Iran, oil sanctions led to medical shortages which are widely believed to have caused many additional deaths. Those suffering from cancer experienced severe downturns in their access to lifesaving treatments, ${ }^{63}$ as have those suffering from haemophilia, thalassemia, and other complex diseases. ${ }^{64}$ Restrictions on oil sales from Iraq in the 1990 s were associated with many tens of thousands of civilian deaths. ${ }^{65}$ As spending on health and sanitation declined, sanctions coincided with steep rises in tuberculosis, measles and typhus. ${ }^{66}$ They also generated

\footnotetext{
${ }^{61}$ Fabre, Economic Statecraft, 51.

${ }^{62}$ Escribà-Folch, "Authoritarian Responses to Foreign Pressure," 705; Damrosch, "The Collective Enforcement of International Norms," 74; Weiss et al, "Economic Sanctions and their Humanitarian Impacts"; Hultman and Peksen, "Successful or Counterproductive Coercion?"; Dursun Peksen (2011) "Economic Sanctions and Human Security: The Public Health Effect of Economic Sanctions," Foreign Policy Analysis 7.3: 237-51.

${ }^{63}$ Shohreh Sahabi et al (2015) "The Impact of International Economic Sanctions on Iranian Cancer Healthcare," Health Policy 119: 1309-18, at 1310.

${ }^{64}$ Mehran Karimi and Sezaneh Haghpanah (2015) "The Effects of Economic Sanctions on Disease Specific Clinical Outcomes of Patients with Thalassemia and Hemophilia in Iran," Health Policy 119: 239-43.

${ }^{65}$ Michael Blake cites the famous claim that oil sanctions led to half a million additional child deaths. Blake, "Bad Men and Dirty Trade," in Wenar et al, Beyond Blood Oil, 37-49, at 41. That figure has been seriously undermined by subsequent empirical work. But even critics of the figure accept that child mortality increased significantly during the sanctions period. See Tim Dyson and Valeria Cetorelli (2017) "Changing Views on Child Mortality and Economic Sanctions in Iraq: A History of Lies, Damned Lies and Statistics," BMJ Global Health 2.2: 1-5.

${ }^{66}$ Karen Morin and Stephen Miles (2000) "The Health Effects of Economic Sanctions and Embargoes," Annals of Internal Medicine 18.132: 158-61. Because of their very broad humanitarian consequences, Fabre considers Iraq the 'paradigmatic example of unjustified sanctions.' Fabre, Economic Statecraft, 75.
} 
significant economic declines for third party countries dependent on oil imports or whose economies were closely tied to Iraq's. ${ }^{67}$ The oil embargo in Syria also appears to have contributed to a severe economic downturn, increasing unemployment, and triggering significant cuts to welfare benefits. Water supply and sanitation have suffered, leading to an increase in deadly waterborne infections, especially in children, ${ }^{68}$ and people suffering from long-term health conditions have again experienced great difficulties in accessing life-saving medicines. ${ }^{69}$ Meanwhile figures close to the elite have benefited considerably from new black market opportunities. Sanctions do not, however, appear to have driven the Syrian regime to engage in political reform. ${ }^{70}$ The same can be said for the cases of both Iraq and Iran.

I do not claim here that the emerging evidence is decisive. In fact, when assessing the impact of breaking off oil purchases we must confront a lack of systematic evidence. Oil sanctions have not often been employed, and remain rather ill-studied. ${ }^{71}$ But it is clear that in every major case since the end of the Cold War, oil sanctions have led to significant numbers of civilian deaths, including deaths of many children and of others unconnected to the ruling regime. ${ }^{72}$ Meanwhile, oil sanctions have not yet led to any significant instances of political inclusion or human rights reform.

On the basis of both effectiveness and proportionality, therefore, the proposal that we ought to break off oil purchases experiences difficulties. Whereas success is highly uncertain,

\footnotetext{
${ }^{67}$ Canes, "Country Impacts of Multilateral Oil Sanctions," 142-3.

${ }^{68}$ Waleed al Faisal (2012) "Syria: Public Health Achievements and Sanctions," The Lancet 379: 2241.

${ }^{69}$ Kasturi Sen et al (2012) "Syria: Effects of Sanctions and Conflict on Public Health," Journal of Public Health 35.2: 195-9.

${ }^{70}$ Peter Harling (2012) “Collectively Failing Syrian Society,” Foreign Policy 24th January.

${ }^{71}$ Van de Graaf, "The 'Oil Weapon' Revisited," 145.

${ }^{72}$ Wenar's response to arguments of that type is to raise the question of moral baselines. The status quo in world politics - according to which we may buy oil from unaccountable leaders - also, he points out, leads to many civilian deaths. Wenar, "Reply to Blake and Mehdiyeva," 122. Note however that the deaths which are said to have been caused by sanctions on oil-exporting countries like Iraq are deaths over and above the level of deaths statistically 'expected' in the brutal regimes in question. See e.g. Dyson and Cetorelli, "Changing Views on Child Mortality and Economic Sanctions."
} 
significant harms to civilians appear to be very likely. It might, to be sure, be the case that any humanitarian suffering can be justified on the basis of long-term progress. ${ }^{73}$ Perhaps the march to greater accountability is simply a very long one which will eventually pay dividends. I do not seek to rule out that possibility. But civilian deaths cannot be outweighed by hope alone: any argument along these lines must show that the chance of significant progress for many people is capable of outweighing the very likely harms to the people who are likely to die, or experience severe suffering, as a result of oil sanctions. ${ }^{74}$ Here there are two distinct challenges. First, we must show that the progress in question is capable of morally outweighing the likely harms. Defenders of so-called 'Limited Aggregation' have argued that grievous harms to small numbers of people can only be outweighed by avoided harms to larger numbers of people if the latter harms are, individually, at least similarly grave. The defender of sanctions must engage with this challenge, by showing that gains in many peoples' political inclusion can morally outweigh even small numbers of additional deaths. Second, there is the epistemic challenge. At present, we have several cases in which a policy of oil sanctions has intensified suffering, but we do not yet have any cases where the result has been a transition to more inclusive or accountable governance. Whereas humanitarian costs appear all but certain, in the absence of successful real-world cases we do not yet know how to assign reliable probabilities to the prospects of lasting political reform. This makes the weighing of expected harms and expected benefits difficult to say the least. ${ }^{75}$

\section{ii. Threat versus Imposition}

\footnotetext{
${ }^{73}$ Wenar, Blood Oil, 298-9.

${ }^{74}$ See for instance T. M. Scanlon (1998) What We Owe to Each Other (Cambridge, Mass.: Harvard University Press), 239-40; Frances Kamm (2007) Intricate Ethics (Oxford: Oxford University Press), 484-86; Alex Voorhoeve (2014) “How Should We Aggregate Competing Claims?" Ethics 125: 64-87; Larry Temkin (2012) Rethinking the Good (Oxford: Oxford University Press), 33-37.

${ }^{75}$ For a sophisticated account of how to make proportionality calculations in cases where likely harms and goods are uncertain, see Patrick Tomlin (2019) "Subjective Proportionality," Ethics 129: 254-83.
} 
There is a second way of responding to concerns about the effectiveness and proportionality of sanctions. This is to highlight the potential systemic effects of threats. It has been suggested that the threat of sanctions can be almost as effective in securing policy change in target countries as their actual imposition. ${ }^{76}$ Regimes which are vulnerable to the application of economic pressure may choose to comply as soon as sanctions are threatened; regimes which fail to respond appropriately to threats, by contrast, are scarcely more likely to respond positively to their actual imposition. ${ }^{77}$ But crucially, threats of sanctions, as opposed to their imposition, may be associated with far fewer negative humanitarian effects in target countries. We would not, of course, expect threats to be effective if they are never followed through on. But if the threatened sanctions are eventually imposed in some cases of non-compliance with human rights norms, there might be an overall deterrent effect when it comes to human rights abuses. ${ }^{78}$ Threatening to break off trade with dictatorships might even remove an incentive for such regimes to emerge in the first place. ${ }^{79}$

For this argument to succeed as a defence of the imposition of sanctions in those cases requires us to weigh the negative effects on civilians of applying sanctions sometimes - a

\footnotetext{
${ }^{76}$ Dean Lacy and Emerson Niou (2004) "A Theory of Economic Sanctions: The Role of Preferences, Information and Threats," Journal of Politics 66.1: 25-42; Drezner, "Sanctions Sometimes Smart"; Hovi, Huseby, and Sprinz, "When Do (Imposed) Economic Sanctions Work?"

${ }^{77}$ Hovi, Huseby, and Sprinz, "When Do (Imposed) Economic Sanctions Work?", 379.

${ }^{78}$ Though I cannot develop it here, there is an interesting parallel in this respect between the case of sanctions and the case of the prosecution of dictators once they leave office. Threatening prosecution may make dictators more likely to engage in violent repression in the short and medium term. But a regime in which dictators are often prosecuted may make the emergence of dictatorship - or the commission of the most serious abuses - systemically less likely. For a discussion of this issue see Kathryn Sikkink (2011) The Justice Cascade: How Human Rights Prosecutions Are Changing World Politics (London: W.W. Norton).

${ }^{79}$ Pogge, World Poverty and Human Rights, 158-61. In fact, many empirical scholars are less certain than Pogge that our willingness to buy resources does serve to incentivize coup attempts. Michael Ross suggests that the chances of success are so low, and the up-front costs so high, that it is implausible that coup attempts are motivated by a 'honeypot' effect. Ross, The Oil Curse, 161. For further claims that oil wealth does not correlate with the probability of coups, see Anca Cotet and Kevin Tsui (2013) "Oil and Conflict: What Does the Cross Country Evidence Really Show?" American Economic Journal: Macroeconomics 5.1: 49-80, and Paul Collier and Anke Hoeffler (2005) "Coup Traps: Why Does Africa Have So Many Coups D'etat?” Department of Economics Working Paper, University of Oxford.
} 
necessary part of the deterrent effect - against the positive effects on civilian populations of a broader regime of credible threats of sanctions. A regime of threats accompanied by selective imposition might well be found, on the score of proportionality, to be more defensible than a thoroughgoing policy of imposition.

Can this response serve as a defence of the across-the-board cessation of trade with dictators? It seems clear that it cannot, and indeed is not designed to. The response makes traction on the score of proportionality precisely by conceding that in many or most cases sanctions will not be applied. We might generate a generalised movement towards human rights observance, so the response suggests, by sanctioning some dictators and merely threatening the rest. While such a policy cannot therefore justify a general policy of cessation, it might still suffice to justify instances of cessation. Any such justification must, however, explicitly identify who is likely to suffer and who is likely to benefit from the policy. It is widely thought to be easier to justify harms to the innocent if the same innocent actors are the intended beneficiaries of a policy (such as the imposition of sanctions). But in the case of a policy of deterrence, the beneficiaries are likely to be distinct from those who will suffer harms. The beneficiaries, it seems, will be individuals in other states. Scholars who have pinpointed the efficacy of threats argue that it is precisely the threat of sanctions, rather than their imposition, which is effective in changing behaviour in the countries which are at the receiving end of those threats. Imposition is a necessary backdrop to a policy of issuing realistic threats, but there is no good reason, defenders claim, to expect that the eventual imposition of sanctions will have any positive effects in the countries to which they are applied. To the contrary, these scholars suggest that if credible threats have already failed, it is unlikely that imposition will succeed in changing the direction of policy. ${ }^{80}$ The beneficiaries of a policy of threats backed

${ }^{80}$ Lacy and Niou, "A Theory of Economic Sanctions," 27; Hovi, Huseby and Sprinz, "When Do (Imposed) Economic Sanctions Work?" 
by selective imposition, then, will be the citizens of other countries who may see an improvement in their human rights situation. By contrast, it will be the citizens of countries where sanctions are imposed who will in all likelihood bear the costs of making that regime of threats credible.

Such a policy will find very little support from non-consequentialist theories of just war. It might be thought that wars aimed at punishing some states for wrongdoing are capable of being justified on wider deterrent grounds. But in fact, it appears that wars are formidably hard to defend from such a perspective, precisely because they harm innocent civilians who are not appropriate objects of punishment. ${ }^{81}$ If the cautionary notes we have thus far sounded about the humanitarian effects of sanctions are sound, then the selective imposition of sanctions on deterrent grounds appears to face the same problem. But even on purely instrumental grounds, the policy of deterrence may be hard to justify, simply because it involves predictable reversals to the position of some of the most oppressed people in the world. To sum up, then, a recognition of the deterrent role of sanctions is not capable of justifying the imposition of sanctions on all dictators. If it is to justify imposition in some cases, this justification would have to lean on the wider systemic effects of a regime of credible threats, rather than any evidence that sanctions will succeed - where threat has failed - in helping the citizens of the countries they are imposed upon. But here it seems that defending the likely harms to innocent civilians on the basis that they might improve the prospects of outsiders is not an easy task.

\section{$\underline{\text { Non-Instrumental Arguments }}$}

${ }^{81}$ Victor Tadros (2014) "Punitive War," in Helen Frowe and Gerald Lang (eds) How We Fight. Oxford: Oxford University Press, pp. 18-37, at 32-34. 
Given the apparently limited prospects that imposing economic sanctions will succeed in better protecting dictators' subjects from abuses, empirical scholars have expressed puzzlement that states resort to them at all - and, indeed, resort to them often. ${ }^{82}$ One possible explanation is that outsiders feel they ought to cease trade because they are obliged to send out a signal to dictators - and to others who might engage with them - that they are in some sense moral outlaws. 'Economic sanctions are not used merely to block or deter the commission of human-rights violations,' as Fabre notes. 'They are also used as a way to express condemnation of those deeds.' The thought is that 'Faced with such grievous wrongdoing, we must at least do something., ${ }^{83}$ This suggests an expressive argument for sanctions.

Nili, too, is clear that our duty to break off trade with dictatorships holds 'independently of any prospects of improved outcomes for others.' And this is fortunate, on his view, because advocates of sanctions are unable to show with any confidence that they will make things better for the oppressed. ${ }^{84}$ The reason for cessation on his account, though, is the preservation of the moral integrity of liberal democratic societies. We believe that citizens ought to be participants in their own self-government - including decision-making about the sale of precious resources - and as a result trading with countries where governments do not involve their own subjects in the relevant decisions is an exercise in hypocrisy. Such a reason for cessation stands even if we have no grounds for confidence that the poor will be made better off, or given greater access to the reins of political power. 'Our own decency,' as Nili puts it, 'must be the grounds' for cessation. $^{85}$

A third non-instrumental basis for cessation is also possible. Below I will consider a consent- or property-based argument, which suggests that we should cease our purchase of

\footnotetext{
${ }^{82}$ See e.g. Pape, "Why Economic Sanctions Do Not Work."

${ }^{83}$ Fabre, Economic Statecraft, 62.

${ }^{84}$ Nili, "Conceptualizing the Curse," 112.

${ }^{85}$ Ibid, 105.
} 
certain goods - here, forms of public property - simply because they are not the property of dictators. Respect for basic liberal principles such as consent renders our purchase of goods from anyone other than their owners illicit.

My aim in this section is not to adjudicate between expressive, integrity-based or consentbased justifications, but to assess the normative weight that any such argument will possess. Whereas standards of effectiveness and proportionality appear clearly relevant to instrumental arguments, it is not immediately obvious that the same can be said for non-instrumental arguments. When it comes to expressive arguments, in particular, the criterion of effectiveness struggles to find a foothold. Consider the cause of insurrection against a despot. We might justify otherwise futile acts of resistance against tyrants on the grounds that they will one day serve to embolden rebels with more realistic prospects of success, for instance. Revolutionary efforts with little chance of coming to fruition have been defended on this basis. ${ }^{86}$ But if the distinction between instrumental and non-instrumental justifications is to remain clean, the justification for cessation cannot be that it will serve longer-term goals. Cessation will be justified even if it does not make political change more likely, whether now or later. Construed as an expressive act at least, it is difficult to know what it would even mean to apply standards of effectiveness to such an act, ${ }^{87}$ beyond the basic question of whether the relevant idea is clearly communicated.

But the standard of proportionality is still, I would argue, highly relevant. Sticking to our moral principles may sometimes be valuable even if it advances no-one's wellbeing. But it cannot be justified regardless of the scale of costs to human wellbeing. In this section my focus will be on the costs that non-instrumental justifications appear capable of justifying. This question loses interest if, as Nili has suggested, things really cannot get any worse for the

\footnotetext{
${ }^{86}$ Lea Ypi (2014) “On Revolution in Kant and Marx," Political Theory 42.3: 262-287.

${ }^{87}$ Cf. Fabre, Economic Statecraft, 63.
} 
inhabitants of at least some dictatorships. ${ }^{88}$ But in the last section we noted evidence that things often can, in fact, get worse for many of the victims of dictators. Even in a brutal regime which wholly excludes its subjects from power, significant setbacks to those who are excluded should still be treated as morally very weighty. If it is true that torture, disappearances, and extrajudicial killing spike in response to the imposition of sanctions, ${ }^{89}$ then we need some way to assess whether those costs are justified. ${ }^{90}$

Weighing negative outcomes against non-instrumental gains is certainly not easy. But that does not obviate the need to try. Joy Gordon has argued that using sanctions to send a moral message (such as the condemnation of tyrants) is not justifiable if it comes at the cost of hurting vulnerable people. ${ }^{91}$ Given the findings we have discussed in this paper, this would appear to render expressive arguments for sanctions largely toothless. Though initially attractive, Gordon's view is a little too simple however. There must be cases where small costs to victims are a reasonable price to pay for repudiating the practices that harm them. But there must also come a point where the costs incurred become too high. One implication of Nili's view is that we can justifiably pursue cessation even if it makes conditions somewhat worse for the subjects of dictatorships. But where can we locate the limit case? On Nili's view the limit arises once cessation hinders physical survival on a massive scale. ${ }^{92}$ Here I would say two things. First, there are grounds for believing that any across-the-board cessation of trade will

\footnotetext{
88 Shmuel Nili (2019) "Global Poverty, Global Sacrifices, and Natural Resource Reforms," International Theory 11.1: 48-80, at 73.

${ }^{89}$ Peksen, "Better or Worse?" 69-74.

${ }^{90}$ Another possibility is that we might implement side-policies to offset any negative effects. Nili endorses my suggestion that if we were to implement Wenar's proposals, we would also need to implement side-policies mitigating any negative humanitarian consequences (Nili, "Global Poverty, Global Sacrifices," 73. See Armstrong (2017) Justice and Natural Resources: An Egalitarian Theory. Oxford: Oxford University Press, chapter 7, section 2). Nevertheless, it is questionable whether the 'targeted injections of funds and goods' Nili has in mind will suffice to offset the costs incurred by people who have been tortured or disappeared. If not, then we must still engage with the question pursued in this section, of how much hardship non-instrumental arguments can justify.

${ }^{91}$ Gordon, "A Peaceful, Silent, Deadly Remedy," 138.

${ }^{92}$ Nili, Conceptualizing the Curse," 115.
} 
cost many lives. If, as Nili suggests, this cost is too high, then cessation will be ruled out. But second, the suggested standard seems to set the moral bar too high. It is not obvious why our integrity is weighty enough to justify cessation even if the effect is merely to significantly increase arbitrary imprisonment and torture, or to worsen diet and health outcomes across the board, say - or indeed to make political reform less likely.

I believe that we can reach a similar judgement when it comes to consent- or propertybased justifications. On such views, outsiders should break off trade not because doing so will promote democracy or human rights more generally, but because proper respect for the property rights of people living in dictatorships demands it. If 'the people' own domestic natural resources, then for outsiders to buy them from dictatorships without the people's consent appears to violate their property rights. ${ }^{93}$

This standard for triggering cessation does not concern, to be clear, whether citizens benefit from resource sales, but whether they have appropriately authorised those sales (in principle they might consent but not benefit, or indeed benefit without having consented). Here the details of the relevant proposals at hand may make a difference to how we assess the normative weight of consent. Nobody, to my knowledge, has suggested that the actual consent of the people to specific sales of public property - such as natural resources - is necessary for trade to be permissible. If it were, international trade would presumably grind to a halt because not even in democracies are citizens consulted as a matter of course about such sales. For Pogge, we are obliged to cease buying public property from dictators if the people have

\footnotetext{
${ }^{93}$ Wenar, "Realistic Reform of International Trade and Resources," in Alison Jaggar (ed) Thomas Pogge and His Critics (Cambridge: Polity), 123-150, at 137. Commentators have sometimes wondered whether Wenar's defence of public property is merely pragmatic in character. See for instance Anna Stilz (2018) "Does a Country Belong to Its People?" in Leif Wenar et al, Beyond Blood Oil (Lanham MA: Rowman and Littlefield), 89-103, at 91. Shmuel Nili suggests that Wenar still owes us a deep moral defence of public property of the type Nili himself provides. See Nili (2019) "The Idea of Public Property," Ethics 129: 344-369, at 346. I do not seek to resolve this issue here, because whether the defence of public property is deep or merely pragmatic, we still need to know what kinds of costs can justly be incurred in deference to it.
} 
previously, and democratically, passed a constitutional clause explicitly indicating that the emergence of dictatorship would vitiate their consent. An independent Democracy Panel could then judge difficult cases. ${ }^{94}$ For Wenar, cessation is mandatory if citizens have not had the opportunity to give their opinion one way or another, in suitably un-coerced circumstances involving the free exchange of information about sales, and the ability to object to them without incurring severe costs. ${ }^{95}$

Pogge's proposal does not yet generate any immediate action-guiding conclusions for outsiders, because no country in the world has passed the kind of constitutional clause he has in mind. His argument is primarily a suggestion that they ought to do so. ${ }^{96}$ But we can still inquire what normative weight such a reform would have should it come to pass in the future. The kind of explicit statement Pogge imagines does appear to give us a powerful reason for ceasing purchases should a dictatorship subsequently come to power. Even here, though, I am not sure it would always provide a decisive reason, all-things-considered. The decision whether to cease trade should still, it seems to me, be reviewable both in light of our emerging understanding of the effects of cessation on the oppressed, and in light of our understanding of the performance of alternative strategies for encouraging the restoration of democracy - on which more shortly. The decisions we make here cannot, it seems to me, be independent of the humanitarian consequences. The kind of case Wenar has in mind, by contrast, does not involve the explicit withdrawal of consent to trade. Rather it sketches a set of standards according to which (explicit or tacit) consent can be judged to be operative. These are intended to be very minimal standards - indeed Pogge suggests that they could be met in autocratic regimes without too much difficulty, ${ }^{97}$ in which case our duty to withdraw trade from dictatorships

\footnotetext{
${ }^{94}$ Pogge, World Poverty and Human Rights, 161-2.

${ }^{95}$ Wenar, Blood Oil, 228.

${ }^{96}$ Pogge, World Poverty and Human Rights, 158-72.

97 Thomas Pogge (2010) "Responses to the Critics," in Alison Jaggar (ed) Pogge and His Critics. Cambridge: Polity, pp. 175-250, at 225.
} 
becomes moot. Perhaps the best we can say is that absent such conditions, we do not know whether the people consent or not. Nili conjectures that, in light of the likely consequences of cessation, citizens of many resource-cursed dictatorships probably would consent to continued trade if given the choice. ${ }^{98}$ But we do not know. In general, though, the lack of explicit consent one way or another seems to me to weigh less heavily than its explicit withdrawal. If so the cautions I expressed about holding firm to cessation in Pogge's case would apply a fortiori here. Non-instrumental arguments do appear to give us reasons for taking cessation seriously, and perhaps powerful reasons. But if the empirical findings we have considered thus far are robust, non-instrumental arguments for sanctions on dictatorships will also be much harder to make than their supporters commonly recognise.

\section{Withdrawing or Extending Trade?}

Thus far, I have argued that the case for cessation - that is, the imposition of a collective ban on purchasing goods from dictatorships, whether this is to apply to all goods or only to some is more difficult to make than our critics have suggested. The discussion so far has, however, focused on withdrawing purchases - stepping back, that is, once a trading relationship is already in place. But it might be responded that my arguments do not show - and have not attempted to show - that we do anything wrong merely by refusing to enter into such relations in the first place. Where no trading relationship exists, my argument does not establish that we have any moral reason to enter into one. In our globalised world, of course, pretty much all states trade with each other in some way - even when some form of sanctions is in place. Hence perhaps we should reformulate the response: even if we have reasons - however regrettable -

\footnotetext{
${ }^{98}$ Shmuel Nili (2016) "Liberal Integrity and Foreign Entanglement," American Political Science Review 110.1: 148-159, at 155 .
} 
to maintain existing trading relationships, perhaps we should refrain from extending or deepening those relationships. I have not said anything yet to suggest that such a position would be morally suspect.

I will not attempt to refute that possibility entirely. But we did note earlier that a full appraisal of the case for sanctions requires us to also scrutinise other available options for reforming dictatorships. All I want to note here, by way of closing, is that the empirical literature on trade provides some grounds for believing that increasing trade may actually be the most powerful weapon we possess by way of which to encourage the reform of dictatorships. The overall relationship between democracy, human rights, and trade is a large and highly contested topic, not least because some free market reforms imposed on developing countries in the past have apparently been associated with worsening respect for human rights, including physical integrity rights. ${ }^{99}$ But 'structural adjustment' policies notwithstanding, it has often been suggested that integration into global trade is associated with improvements in the quality of governance, ${ }^{100}$ and in the rule of law, ${ }^{101}$ and that integration into global trade and investment patterns is key to promoting respect for human rights, ${ }^{102}$ including both physical security rights and political participation rights. ${ }^{103}$

Why might this be the case? At least two mechanisms have been suggested which are plausible on their face. First, it has been suggested that gains from trade can help to smooth the process of political reform by allowing rulers to offset any costs incurred by supporters as a

\footnotetext{
99 Rodwan Abouharb and David Cingranelli (2006) "The Human Rights Effects of World Bank Structural Adjustment, 1981-2000," International Studies Quarterly 50.2: 233-262.

100 Fahim Al-Marhubi (2005) "Openness and Governance: Evidence Across Countries," Oxford Development Studies 33.3-4: 453-471.

${ }^{101}$ See e.g. Roberto Rigobon and Dani Rodrik (2005) "Rule of Law, Democracy, Openness, and Income: Estimating the Interrelationships," Economics of Transition 13.3: 533-564.

${ }^{102}$ Clair Apodaca (2001) "Global Economic Patterns and Personal Integrity Rights After the Cold War," International Studies Quarterly 45.4: 587-602.

${ }^{103}$ David Richards, Ronald Gelleny, and David Sacko (2001) "Money with a Mean Streak? Foreign Economic Penetration and Government Respect for Human Rights in Developing Countries," International Studies Quarterly 45.2: 219-239.
} 
result of reform, transforming reform from a zero sum into a positive sum outcome. ${ }^{104}$ Martin Ravallion has made a parallel case about the role of foreign aid in easing political transitions, by way of which an injection of income can help overcome stumbling blocks on the road to reform. ${ }^{105}$ This claim, of course, might produce moral unease: we might well believe that domestic elites should bear the costs of reform, and that compensating them for their pains is far from being morally required. But granting that dictators and their allies are not entitled to compensation is not the same thing as establishing that it is wrong to provide it, or indeed that we have no duty to provide it. Rewarding evil-doers is a pro tanto moral bad. But it may be preferable to allowing millions to continue to live under tyrants. ${ }^{106}$ When it comes to the worst abusers of human rights, the early steps towards reform may often involve some form of instrumental bargaining, in the hope that this can sow the seeds of deeper change, including by creating new constituencies which stand to benefit from further reform. ${ }^{107}$

Second, trade - and especially trade in a diverse range of goods - facilitates the emergence of a strong middle class. ${ }^{108}$ As is familiar from many accounts of political development, this emergence in turn generates claims for political inclusion. ${ }^{109}$ Other things being equal, trade in a more diverse set of goods looks like being more beneficial here than trade in a narrow set. The more diverse the economy, the harder it is going to be for the ruling regime to securely capture economic rents, the more sources of independent economic power there are going to be, and the more powerfully demands for political inclusion are therefore

\footnotetext{
104 Emilie Hafner-Burton (2005) "Trading Human Rights: How Preferential Trade Agreements Influence Government Repression," International Organization 59.3: 593-629, at 607.

${ }^{105}$ Martin Ravallion (2014) "On the Role of Aid in The Great Escape," Review of Income and Wealth 60.4: 967-984.

${ }^{106}$ See also Pattison, Alternatives to War, 150.

${ }^{107}$ Thomas Risse and Kathryn Sikkink (1999) "The Socialization of International Human Rights Norms Into Domestic Practices: Introduction," in Risse et al (eds) The Power of Human Rights: International Norms and Domestic Change. Cambridge: Cambridge University Press, 1-38, at 10.

${ }^{108}$ Peksen, "Better or Worse?"

109 Seymour Lipset (1959) "Some Social Requisites of Democracy: Economic Development and Political Legitimacy," American Political Science Review 53.1: 69-105.
} 
going to resonate. If it is indeed plausible, this story would provide further reason - beyond the imperatives of avoiding dangerous climate change - for assisting or persuading oil-producing countries along the road to economic diversification. ${ }^{110}$ But rather than ceasing trade with oil exporters, progress will likely involve fostering a wider variety of exports: enhancing and extending, that is, rather than cutting, trading links.

I will not claim that the empirical evidence here is decisive and unequivocal by any means. According to some commentators, for instance, even if openness to trade eventually leads to benefits for citizens, the transition to greater openness can be fraught. Regimes which are wholly closed to trade can be very stable, and greater openness can introduce a period of greater instability before the long-term benefits of openness come to fruition. ${ }^{111}$ There is at least a plausible story, however, which suggests that extending and deepening trade can lead to political reform. To take an even more fine-grained approach, one suggestion has been that if we care about human rights, the most promising policy package would involve the provision of benefits through Preferential Trade Agreements, with the realistic threat of the withdrawal of those additional benefits (rather than the withdrawal of trade per se) hanging in the background. This package emphasises carrots - and the removal of carrots - rather than sticks. The most advanced example of this kind of policy has been the European Union's Cotonou Agreement, signed with 78 countries from Africa, the Caribbean and the Pacific, in which the EU delivers non-reciprocal access to markets in some goods in return for specific human rights commitments in vendor countries. Success in meeting these commitments is then regularly reviewed, with preferential trading privileges withdrawn in serious cases of default. These agreements 'provide an economic motivation to promote human rights policy reforms that

\footnotetext{
${ }^{110}$ For a discussion of the nature and basis of outsiders' moral duty to promote post-oil development options, see Chris Armstrong (2019) "Decarbonisation and World Poverty: A Just Transition for Fossil Fuel Exporting Countries?" Political Studies (online early).

${ }^{111}$ Ian Bremmer (2006) The J Curve: A New Way to Understand Why Nations Rise and Fall. New York: Simon and Schuster, 3-26.
} 
would not otherwise be implemented, and they do so in a relatively short time horizon.'112 Cases where threats to human rights have been reversed in response to the combination of threat and persuasion are said to include Togo and post-civil war Rwanda. ${ }^{113}$ Preferential Trade Agreements appear to have sustained democratization processes, ${ }^{114}$ and Free Trade Agreements more broadly appear to have been successful in numerous cases in preventing unstable democracies from backsliding into autocracy. ${ }^{115}$

One way to capture the different options open to us when dealing with dictatorships is to distinguish 'leverage' - the use of diplomatic pressure, economic sanctions, and so on - from 'linkage' - the building up of greater and more diverse links, including trading links (but also cultural, personal and intellectual links) between our own societies and those blighted by dictatorship. According to Levitsky and Way, whereas leverage has typically failed, linkage has often exerted an incremental but nevertheless significant influence in the direction of democratisation. This, they claim, is for a variety of reasons: because with greater linkage, abuses overseas become more visible within our own societies; because linkage helps to inculcate democratic norms; because it builds the capacity of reform groups within dictatorships; and because it gives those reform groups an international visibility which can later protect them from abuse. ${ }^{116}$ If this story is correct, then the conclusion for our purposes is an interesting one. Perhaps, in practice, our best chance at encouraging the reform of dictatorships is to trade with them more, rather than less. We might have reason not only to be

\footnotetext{
${ }^{112}$ Hafner-Burton, "Trading Human Rights," at 607.

${ }^{113}$ Emilie Hafner-Burton (2013) Forced to be Good: Why Trade Agreements Boost Human Rights. Ithaca: Cornell University Press, 143, 156.

${ }^{114}$ Mark Manger and Mark Pickup (2016) "The Coevolution of Trade Agreement Networks and Democracy," Journal of Conflict Resolution 60.1: 164-191.

115 Xuepeng Liu and Emanuel Ornelas (2014) "Free Trade Agreements and the Consolidation of Democracy," American Economic Journal: Macroeconomics 6.2: 29-70.

${ }^{116}$ Steven Levitsky and Lucan Way (2005) "International Linkage and Democratization," Journal of Democracy 16.3: 20-34.
} 
circumspect about arguments for cessation, but to be open to extending trade links rather than severing them.

The arguments of this section raise an important question about duties to engage in trade. I have not claimed that there is a general duty to trade with other societies. In fact we have reason to be cautious about any such argument, since the claim that there is such a duty has been used to justify colonial wars and other abuses. ${ }^{117}$ But it is highly plausible that we can possess a derivative duty to trade with disadvantaged societies where that is useful in promoting their development. If the advantaged possess a duty to ease poverty and suffering elsewhere, ${ }^{118}$ an important question arises concerning the optimal means of acting upon that duty. One familiar argument holds that we should prefer 'trade' to 'aid,' because trade better promotes the autonomy of people in developing countries, rather than leaving them dependent upon the often fickle and conditional delivery of aid. ${ }^{119}$ If the empirical evidence canvassed in this section is robust, it suggests that we have a second, and much less familiar, reason for preferring trade as a policy option. If extending and deepening trade can help to create additional bases of socio-economic power in dictatorships, as well as smoothing the path of political inclusion, it may be a still more important vehicle of global reform than we have so far recognised.

\section{Conclusions}

There is no doubt that the question I have been tackling in this paper represents a major ethical quandary, where any answer provokes considerable unease. The problem we face in

\footnotetext{
117 See for instance Anthony Anghie (1996) "Francisco de Vitoria and the Colonial Origins of International Law," Social and Legal Studies 5.3: 321-36.

${ }^{118}$ In principle this duty might be based upon either capacity to help, contribution to the problem, or both. For a careful analysis of these foundations for a duty to assist, see Christian Barry and Gerhard Øverland (2016) Responding to Global Poverty: Harm, Responsibility, and Agency (Cambridge: Cambridge University Press).

${ }^{119}$ See for instance the discussion in Aaron James (2012) Fairness in Practice: A Social Contract for the Global Economy (Oxford: Oxford University Press), chapter 7.
} 
determining whether to continue, or terminate, trade with dictatorships in many ways resembles that faced by humanitarian NGOs which must decide whether to continue to engage with those dictatorships, or withdraw. Jennifer Rubenstein calls this the problem of 'spattered hands,' in which actors must decide between two apparent injustices: 'contributing to violence and intimidation perpetrated by others, and "pulling the rug" out from under innocent civilians by depriving them of basic services on which they have reasonably come to rely., ${ }^{120}$

My suggestion has been that claims that the answer here is straightforward - that cessation is clearly morally required - are too quick. Insofar as we have evidence to go on from the sanctions literature, the message is sobering. There is, it seems, depressingly little reason to believe that disengagement will make things better for the oppressed, at least in the short term. And it may well make things worse. We certainly ought to vigorously investigate any critical levers we have which promise to make things better for the oppressed. But the signs are that across-the-board disengagement is unlikely to be helpful. Depending on how the evidence plays out, showing proper concern for the interests of the oppressed may well lead us to the conclusion that we ought to deepen our trading relationships with dictatorships, rather than rupturing them.

${ }^{120}$ Rubenstein, Between Samaritans and States, 11. 